\title{
Validation of a Turkish Version of the Profiles of Organizational Influence Strategies
}

\author{
Saadet Kuru Cetin ${ }^{1}$, Sakir Cinkir $^{2}$ \\ ${ }^{1}$ Assistant professor, Mugla Sitki Kocman University, Graduate School of Educational Sciences, Department of \\ Educational Sciences 48000 Kotekli Campus, Muglağ, Turkey \\ ${ }^{2}$ Associate professor; Ankara University, Faculty of Education Sciences, Department of Educational Management and \\ Policy, 06590 Cebeci, Ankara Ankara University, Turkey \\ Correspondence: Saadet Kuru Cetin, Assistant professor, Mugla Sitki Kocman University, Graduate School of \\ Educational Sciences, Department of Educational Sciences 48000 Kotekli Campus, Muglağ, Turkey.
}

\author{
Received: August 1, $2016 \quad$ Accepted: August 16, $2016 \quad$ Online Published: September 8, 2016 \\ doi:10.11114/jets.v4i10.1780 URL: http://dx.doi.org/10.11114/jets.v4i10.1780
}

\begin{abstract}
Influencing others is at the heart of the management process. Managers use the influencing process for the purposes of controlling workers, using limited sources, implementing organizational change, breaking down the resistance of workers to this change, and enhancing the performance of workers of different from the managers' backgrounds.

This study was carried out on data from two distinct samples $(n=361, n=284)$ by an adaptation of the "Profiles of Organizational Influence Strategies (POIS): Influencing Your Manager (Form M)" and "Profiles of Organizational Influence Strategies (POIS): Influencing Your Subordinates (Form S)", developed by Kipnis and Schmidt (1999) to Turkish culture and findings about the adaptation's validity and reliability values.

In the first sample analyses, the results of the study indicated that the scale had high construct validity and internal consistency coefficients. These six factors were termed as: "Friendliness", "Reason", "Bargain", "Assertiveness", "Higher Authority" and "Coalition". In the second sample analyses, it was found that the scale has a factor structure not much different from the original factor structure. In the data analysis, seven factors are determined by Confirmatory Factor Analysis (CFA) to determine whether these factors are composed of a consistent structure or not. The results of the study indicated that the scale had high construct validity and internal consistency coefficients. These seven factors were called: "Friendliness", "Reason" "Bargain", "Assertiveness", "Higher Authority", "Sanctions" and "Coalition".
\end{abstract}

Keywords: influence, influence strategies, manager, teachers

\section{Introduction}

\subsection{Problem}

People's social environment affects their behavior, interest, communication, persuasion and influence. The ability of people to survive in society mostly depends on their communication skills. Communication has as much importance for individuals as it does for institutions (Tasci and Eroglu, 2007). It may be asserted that communication is the most important dynamic for an organization in sustaining its presence.

Organizational communication has four functions: providing knowledge, ordering, educating and influencing (Tasci and Eroglu, 2007). Providing knowledge has several functions, such as enabling managers to make their decisions accurately and on time and accommodating new members to the organization (Karacor and Sahin 2004).

The ordering function of a communication technique, and it is unilateral. This is a hierarchical form of communication used by managers. Ordering and education/teaching play an important role in getting the employee to know their duties and responsibilities and fulfilling the communication as required. Another important function of ordering is combining and providing coordination. Management easily reaches the workers by means of education and that enables them to fulfill their duties and responsibilities in the organization (Chong, Peng, Fu, Richards, Muethel, Caldas, and Shang, 2015; Chaturvedi and Srivastava, 2015; Erogluer, 2011; Karacor and Sahin, 2004).

Influencing is at the heart of the management process. Managers use the influencing process for the purpose of 
controlling workers (Lo, 2014; Onyekwere, 1989), using limited resources (Cocivera, 2002), implementing organizational change, breaking down the resistance of workers to this change (Dulaimi, Nepal and Park, 2005), and enhancing the performance of workers from different from the manager's backgrounds (Yamaguchi, 2009).

Researchers investigate the notion of influence in order to understand its process better. They approach the notion from various perspectives. The social change perspective has conceptualized influence via power and social interactions (Culves, 1994). Turner, who is opposed to these views, has argued that these standard theories are actually not specific, but are rather assumptions on which the relation between power and influence are stated. According to Turner (2005), standard and triple process theories define the process of influence. Many scientists generally examined the theoretical foundation of influence under four categories: (1) social change perspective (Lo, Ramayah and Wang, 2015; Molm, 1991; Cropanzano and Mitchell, 2005), (2) power perspective (Raven, 1999; Hinkin and Schriesheim, 1990), (3) social interaction and 'social change' and 'power' perspectives as well as the mentioned above (Newton and Burgoon, 1990), (4) multiple influencing perspectives (Fu and Yukl, 2000; Yukl and Fu, 2003).

Social change theory is among the most effective conceptual paradigms, which originated in order to understand behaviors in the working place. The roots of social change trace back to the 1920s (Cropanza and Mitchell, 2005), and social change theorem is interdisciplinary and involves the points of view of anthropology, behavior psychology, sociology, social psychology and economics. The sociologists Blau (1964 as cited in Molm, 1991) and Emerson (1976) and social psychologists Thibaut and Kelly (1959) have contributed to the development of social change theorem. The power perspective is a necessary premise for revealing the power or influencing source behind people's obedience. Supporters of the power perspective are French and Raven (2001), Hinkin and Schriesheim (1990), and Lined (2007). Social interaction perspective traces back to Lewin's (1951, as cited in Ekehammar, 1974; Chatman, 1989) research of behavior. Scientists who adopted this perspective (Ekehammar, 1974; Chatman, 1989) were the first to use the person and environment as concepts in their studies.

According to Ekehammar (1974), interaction theorem synthesizes personalism and situationism. In this theorem, neither the person nor the situation is emphasized. In the interaction theorem, the main source of variety in behavior is the interaction between the person and situation. In multiple perspectives, which are one of the theoretical foundations, the researchers approach the interaction process by aggregating the previous points of view (Bacharach and Lawler, 1980; Kipnis, Schmidt and Wilkinson, 1980; Kipnis, Schmidt, Swaffin-Smith and Wilkinson, 1984; Kipnis and Schmidt, 1988; Turner, 2005; Yukl, 2010). Researchers Bacharach and Lawler (1980) approached the interaction as an "umbrella term". According to this concept, the authority has the right to use power, and effectiveness is a power that emerges from the ability to form decisions through informal change. Power is defined as an interaction where people use power against each other by using their abilities in personal interaction.

In order to measure the concept of influence, the researchers put forward measurement devices for the purpose of setting out in perspectives above. Of these approaches, the most popular and influential tactic classification has been French and Raven's "power based tactics" (1959, as cited French and Raven, 2001). The power types taxonomy was developed by French and Raven (2001) and consists of five various power sources: reward power, coercive power, legitimate power, referent power and expert power.

French and Raven's social-power-based taxonomy evolved three times. In the first change, Raven added quintet taxonomy to the information power. With the second change, Raven differentiated the six-based taxonomy as 14 individual updated taxonomy. Finally, Raven (2008) revealed a 14 individual taxonomy as the power/interactional model. Thus Raven (1992, as cited Getty and Erchull, 2009) upgraded this power-based taxonomy to a multistage model.

Furthermore, French and Raven's (1959, as cited French and Raven, 2001) power-based taxonomy was one of the classification studies of the first influence tactics. French and Raven's studies guided many researchers such as Hinkin and Schriesheim (1990), Schriesheim and Hinkin (1990), Yukl and Falbe (1990), and Kipnis, Schmidt and Wilkinson (1980). This is one of the most powerful sides of this study.

Many researchers have developed tactics to measure the notion of influence and named these "influence tactic[s]" (Falbo, 1977, as cited Culves, 1994; Kipnis, Schmidt and Wilkenson 1980; Hirokowa and Miyahara 1986; Wayne and Ferris, 1990; Yukl and Falbe, 1990). Researchers such as French and Raven (1959, as cited French and Raven, 2001), Raven (2008), Shah and Inamullah (2011), Erchul, Grissom and Getty (2008), Aslanargun (2008), and Erchul, Paven and Whichard (2001) have used organizational influencing tactics for the purpose of investigating the relation between school counseling and social power.

The first systematic approach to measuring influencing tactics was carried out by Yukl (2010) and Kipnis, Schmidt and Wilkinson (1980). Kipnis, Schmidt, Swaffin-Smith and Wilkinson (1984) asserted the pattern of influencing tactics used by managers emerged not because of the experimental approach but because of social power theory. According to 
Kipnis and others (1984), theoretical power-based influencing tactics, which were revealed by French and Raven (1959, as cited French and Raven, 2001), don't include all the influencing tactics that manager's use. Kipnis et al. (1984) claimed that the reason for this was that the classification wasn't stated theoretically and experimentally.

In the first part of Kipnis, Schmidt and Wilkinson's study (1980) they assigned 165 lower-level managers to prepare homework about how they influence upper-level managers, lower-level workers, and workers in the same position. This assignment was analyzed by three moderators and assembled fewer than 370 tactics and 14 categories. In the second part of the same study, the profile (scale) turned into 370 tactics and 58 items. By applying the profile to 58 items to 225 managers, 285 workers, who are in the same position, and 244 lower-level workers, the factor structure was stated. In the second part of the Kipnis and Schmidt (1988) study, the factor structures were taken into account and the profiles of 58 items were gathered under eight subscales. These subscales are assertiveness, ingratiation, rationality, sanctions, exchange, upward appeals, blocking and coalition. The Kipnis and Schmidt study in 1982 reorganized the organizational influencing strategies profile of the first study by Kipnis, Schmidt and Swaffin-Smith and Wilkinson (1980) and transformed it into a commercial scale. In an intercultural study, which Kipnis did with Schmidt, Swaffin-Smith and Wilkinson (1984), the developed version of the scale was applied to American, Australian and English managers.

Kipnis and Schmidt's studies $(1982 ; 1988 ; 1999)$ have undergone some changes through the years and their organizational influencing strategies scale have been reshaped into three different scales as shown in Chart 1 . These scales are: the organizational influencing strategies scale: influencing manager (form $\mathrm{M}$ ), the organizational influencing strategies scale: influencing subordinates (form A), and the organizational influencing strategies scale: influencing coworkers (form C).

At the same time, Schriesheim and Hinkin (1990) used the scale created by Kipnis, Schmidt and Wilkinson (1980) to run a validity and reliability study. The reason behind Schriesheim and Hinkin's study (1990) is that Kipnis, Schmidt and Wilkinson's (1980) scale doesn't show high validity and reliability. Schriesheim and Hinkin carried out their research in four sub-studies. Accordingly, the first study was applied to 34 managers. In Schriesheim and Hinkin's scale, there are six influencing tactics, which were used in Kipnis, Schmidt and Wilkinson's (1980) scale. At the end of the study, it was determined that the scale didn't show a strong validity. In the second study, the scale was applied to 251 managers. As a result of factor analysis, it was concluded that 21 of 27 items had strong validity. In the third study, Kipnis, Schmidt and Wilkinson's (1980) scale of 58 items and 9 influencing tactics was applied to 281 students who were earning a master's degree in business. The outcome of this sub-study was that Schriesheim and Hinkin (1990) reduced the scale to 17 items.

In the fourth and the last study, Schriesheim and Hinkin (1990) finalized the scale with 18 items and applied it to 181 university workers. Their new scale had the following subsections: assertiveness, ingratiation, rationality, coalition, exchange and upward appeal. Beyond these findings, Hochwarter et al. (2000) studied Schriesheim and Hinkin's (1990) renewed scale again. Their study was composed of four subsections. In the end, Schriesheim and Hinkin (1990) concluded that the scale developed by Kipnis, Schmidt and Wilkinson (1980) had low validity and had problems in its design (such as using only one device to gather variables about the sample survey). The other researchers who developed Kipnis, Schmidt and Wilkinson's (1980) scale were Landry, Porter and Lemon (1989). Landry, Porter and Lemon (1989) performed a study to understand the manager's strategy of using power from the teacher's point of view. In this study, items from Kipnis, Schmidt and Wilkinson's (1980) scales were chosen to create a school manager power tactics scale. The pilot study was applied to secondary schools and reported that the scale was valid and reliable.

In the literature, even the researchers Schriesheim and Hinkin (1990), who comprehensively analyzed the Kipnis, Schmidt and Wilkinson (1980) scale, didn't report on its validity. It was seen that the sampling in their study wasn't appropriate for the scale adaptation. The reason for this was that sampling was generally applied to students. Although Schriesheim and Hinkin's studies (1990) brought a different perspective to Kipnis, Schmidt and Wilkinson's (1980) scale, it can be said that their studies weren't appropriate in regard to sampling. 
Table 1. The Improvement of Influence Tactics in Times Developed by Kipnis et al

\begin{tabular}{llll}
\hline & \multicolumn{2}{l}{ Kipnis and Schmidt (1988; 1999) } & \\
Kipnis, Schmidt and & "Profiles of Organizational Influence "Profiles of Organizational Influence "Profiles of Organizational Influence \\
Wilkinson (1980) & $\begin{array}{l}\text { Strategies (POIS): Influence Your } \\
\text { Manager (Form M)" }\end{array}$ & $\begin{array}{l}\text { Strategies (POIS): Influence Your } \\
\text { Subordinates (Form S)" }\end{array}$ & $\begin{array}{l}\text { Strategies (POIS): Influence Your } \\
\text { Coworkers (Form C)" }\end{array}$ \\
\hline Ingratiation & - & - & - \\
- & Friendliness & Friendliness & Friendliness \\
- & Reason & Reason & Reason \\
Rationality & - & - & - \\
- & Bargain & Bargain & Bargain \\
Sanctions & Sanctions & - & - \\
Assertiveness & Assertiveness & Assertiveness & Assertiveness \\
Exchange & - & - & - \\
- & Higher Authority & Higher Authority & Higher Authority \\
Upward Appeals & - & - & - \\
Blocking & - & - & - \\
Coalition & Coalition & Coalition & Coalition \\
\hline
\end{tabular}

Although Kipnis and Schmidt $(1988 ; 1999)$ restructured the influencing tactics in three different scales, the contents of the profile items resemble each other. The definitions of the seven items are as follows: (1) Friendliness: using feelings of friendship with good impressions, praise, and show of good intentions. (2) Bargain: compromising on the mutual change of effects or benefits that the topic brought about. (3) Sanctions: using demand, threat, constant reminders or organizational punishment to influence a person. (4) Assertiveness: making a request constantly and forcefully to change another's mind. (5) Higher authority: applying to senior managers in a hierarchy to change influenced goal. (6) Coalition: asking for support from the other people to change influenced goal, asking for backup. (7) Reason: making the cause of the subject clear by giving logical details and data to support the subject, and taking advantage of logical samples and details to influence a person. In the influencing tactics scale, which was developed by Kipnis and Schmidt (1988-1999), the sanctions were located only in the inferior (subordinate) influencing form, not in the manager and colleague influencing form. The reason for this is that sanction influence only takes place under the authority of managers.

Yukl et al.'s classifications are the most widely used among the other organizational influencing tactics classifications. Yukl restructured these influencing tactics over years by working with different people (e.g., Yukl and Falbe, 1990; Yukl and Fu, 2003; Yukl and Michel, 2006; Yukl and Tracey, 1992). Therefore, Yukl's influence tactics demonstrate a great deal of change over the years as in French and Raven's (1959) and Kipnis, Schmidt and Wilkinson's (1980) studies. According to Yukl (2010: 207), recent researchers have used influencing as a special part of behavior instead of focusing only on power as a potential influencing source. Furthermore, the mode of behavior used to influence one's attitude for a particular purpose is called influencing tactics. Yukl (2010: 217-218) has divided organizational influencing tactics into four categories, each based on a general purpose. These tactics are impression management tactics, political tactics, proactive organizational influencing tactics, and test tactics.

Yukl performed his first study on organizational influence tactics in 1990 with Falbe. The study was an expanded and restructured version of the organizational influence tactic scale of Kipnis, Schmidt and Wilkinson (1980). Yukl and Falbe applied their study on two samples. The first sample was applied to 197 master's students earning their business degree; the second sample was applied to 237 master's students earning business degrees. Yukl and Falbe (1990) removed the sanctions and blocking sizes in Kipnis, Schmidt and Wilkinson's (1980) organizational influence strategies profile, and they created an Influence Behavior questionnaire, with eight subsections: impress upward appeals, exchange, cooperation, ingratiation, persuasion, demand and counseling. Yukl and Trancy removed upward appeal and replaced it with intimacy and present legal ground. Lastly, by adding two subsections (informing and coalitions) to Chavez and Seifert's (2005) studies, Yukl gave the questionnaire eleven subsections (impress, exchange, coalition, ingratiation, persuasion, demand, intimacy, present legal ground, inform)

Influence and influence tactics created an intensive research area in the international literature, and this signifies the importance of researching the same subject in Turkish culture. We have a few studies about influence in education in our country. That's why Kipnis and Schmidt (1999) aim to adapt their organizational influence strategies profile to Turkish culture with the hope that it will advance research about influence tactics. 


\section{Method}

\subsection{Research Sample}

The study has been carried out on data from two distinct samples $(n=361, n=284)$. The first sample is composed of 361 teachers in secondary schools in Ankara province. The second sample is composed of 284 secondary school administrators in Istanbul, Tekirdag, Balıkesir, Izmir, Mugla, Bursa, Kocaeli, Konya, Karaman, Adana, Hatay, Kirsehir, Kirikkale, Zonguldak, Samsun, Trabzon, Ordu, Erzurum, Agri, Malatya, Mus, Gaziantep, and Diyarbakir city centers.

\subsection{Research Instrument and Procedure}

Having obtained permissions, the instrument used in this study is the POIS Influence Strategies Scale by Schmidt and Kipnis. "The Profiles of Organizational Influence Strategies (POIS): Influencing Your Manager (Form M)" is classified into seven categories: "Friendliness", "Reason, "Sanction", "Higher authority", "Assertiveness", "Coalition "", and "Bargain". Each influence tactic is measured by two to six items. The scale is composed of a total of 27 questions,

"Profiles of Organizational Influence Strategies (POIS): Influencing Your Subordinates (Form S)]" is classified into six categories, named as: Friendliness, Reason, and Higher authority, Assertiveness, Coalition and Bargain. Each influence tactic is measured by two to seven items. The scale is composed of a total of 33 questions.

\subsection{Data Analysis}

The Organizational Influence Strategies Profile was bought from the Mind Garden Company for a one-year period of research use and to be applied to 2,000 people. The adaptation process was started later. The profile's original language was English and in the process of adapting it to teachers and managers in Turkish education, the stages that Hambleton and Patsula (1999) suggested in adapting intercultural profile studies were followed. The adaptation of this study of the Organizational Influence Strategies Profile consisted of three stages. In the first stage, the profile items were translated into Turkish by English linguists. In the second stage, language experts determined whether the words, concepts and idioms had the same meanings in both cultures; and in the final stage, the adaptation of the profile was translated.

The process of applying the organizational influence strategies profile to the Turkish group consisted of the following: firstly, the items, instructions and the evaluation sections of the profile were translated from English to Turkish and Turkish to English. Experts translated both profile items into Turkish. The counseling instructors corrected these differences.

In the next stage, in order to determine any inconsistencies between the Turkish and English expressions, a questionnaire using both Turkish and English expressions was prepared and four experts evaluated it. All of the translations were evaluated again, both translations were compared, and it was concluded that no difference in meaning existed between the forms. The profile translated into Turkish was adjusted according to the suggestions of the scale experts. In this way, language validity was achieved.

In order to determine the validity of the scale's language equivalence, the original form of the scale was given to 11 English teachers and 3 school managers. A week later, the Turkish version of the scale was given to the same group again. In comparing the results, the difference between two points set was matched.

Since the scale was applied to a few participants, and it didn't abide by the normal range, Spearman's Rho correlation coefficient was used for the language consistency. According to it, positive and strong consistency was stated in the scale of the teacher's organizational influence strategies to managers, using friendship $(\mathrm{r}=0.967, \mathrm{p}<0.05)$, bargain $(\mathrm{r}=0.998, \mathrm{p}<0.05)$, showing reason $(\mathrm{r}=0.976, \mathrm{p}<0.05)$, assertiveness $(\mathrm{r}=0.970, \mathrm{p}<0.05)$, higher authority $(\mathrm{r}=0.998$, $\mathrm{p}<0.05)$, and coalition with others $(\mathrm{r}=0.763, \mathrm{p}<0.05)$. Therefore it can be said that the Turkish adaptation of the organizational influence strategy profile is quite accurate.

In the scale of the manager's organizational influence strategy to teachers, using friendship $(r=0.957, p<0.05)$, bargain $(r=0.978, p<0.05)$, showing reason $(r=0.996, p<0.05)$, assertiveness $(r=0.980, p<0.05)$, higher authority $(\mathrm{r}=0.900, \mathrm{p}<0.05)$, coalition with others $(\mathrm{r}=0.863, \mathrm{p}<0.05)$, and sanctions $(\mathrm{r}=0.867, \mathrm{p}<0.05)$, positive and strong consistency was stated. Therefore it can be said the Turkish adaptation of the organizational influence strategy profile was quite successful.

First, it was investigated whether there were outliers in the univariate and multivariate of items in both data sets. In cases where the standardized surplus value is above +-3.29 , the existence of the outlier value can be determined (Tabachnick and Fidell, 2001; Stevens, 2002). Whether the outlier degree affects the other degrees depends on the Cook's distance (Cook and Wesberg, 1982 as cited Stevens, 2002) and leverage value (Kalayci, 2009). After all these analyses were finished, it was concluded that there was no outlier value in the data set. Since the managers had no Mahalobonis distance, it was concluded that there was no multivariate outlier value in the data set. In addition, it was stated that there was no negative value in the data sets and no multicollinearity between the items depending on 
tolerance, VIF and condition index. In other words, no tolerance close to 0 , no VIF value higher than 5-10, and no index higher than 30 was observed. For the normality test, the coefficient factor of kurtosis and skewness was observed. As a general rule, the coefficient of kurtosis and skewness is between $(+1-1)$, and that keeps the univariate. At the same time, according to George and Mallery (2003), the coefficient of kurtosis and skewness falling between +2 and -2 indicates that the data set is in the normal range. It was concluded that the number distribution of the items showed neither kurtosis nor skewness.

\section{Profiles of Organizational Influence Strategies (POIS) Analysis Results}

In this part of the study, in order to state whether the factor structure of organizational influence profile is appropriate or not, a confirmatory factor analysis (DFA) was done. In the factor analysis studies, corroborative factor analysis was a great help.

In the confirmatory factor analysis that examines the adaptation of sample data, the hypothesis that was set up for the bond between variables was tested (Kline, 1998; Tabachnick and Fidell, 2001). The different goodness of fit indices was used in the assessment of model adjustment, and these indices had some limited values to determine whether the model would be accepted or not (Brown, 2015; Schermelleh-Engel and Moosbrugger, 2003). Among them, the most commonly used was the chi-square test, the goodness adjustment fit index (GFI), the corroborated goodness fit index (AGFI), root mean square error (RMR or RMS) and root mean square error of approximation (RMSEA).

In the literature, if the value calculated by DFA is below five, it is an indicator of the adaptation of model with data (Sumer, 2000). For the data-model adaptation, it was expected that the GFI and AGFI values would be above 0.90 and that the RMS or standardized RMS and RMSA values would be below 0.05 . Whereas if the GFI value were above 0.85 , the AGFI value above 0.80 , and the RMS value below 0.10 , it is an indicator of the adaptation of model with data (Anderson and Gerbing, 1984).

\subsection{Profiles of Organizational Influence Strategies (POIS): Influencing Your Manager (form M) Analysis Results}

To determine whether the factor structure of the organizational influence profile was appropriate or not, a confirmatory factor analysis (DFA) was done. According to factor loadings, $\mathrm{X}^{2}$ and goodness-of-fit statistics, a three-factor structure was confirmed for Profiles of Organizational Influence Strategies (POIS): Influencing Your Manager (Form M). Items and factor loadings are given in Table 2 . The data showed a reasonable fit to the model, $\left(\chi^{2}=493,78 ; \mathrm{P}=0,000 \mathrm{fd}=\right.$ 283), $\mathrm{X}^{2} / \mathrm{df} 1,74, \mathrm{CFI}=0,97, \mathrm{NNFI}=0,96, \mathrm{GFI}=0,76, \mathrm{AGFI}=0,71$ and $\mathrm{RMSEA}=0,055$.

Schriesheim and Hinkin (1990) conducted POIS analysis with three independent samples to increase confidence in their results. In the first sample, confirmatory factor analysis of the POIS scale indicated that among the model fit values RMSEA (0.085) and GFI (0.75), the second sample fit values was GFI (0.77). In Schriesheim and Hinkin's (1990) study, the participants were postgraduate students. As a result, the POIS Form M forms of the profile were applied to the managers of Turkish secondary schools, and the validity and reliability of the profile were proved. The CFA diagram results for this model were also presented in Figure 1.

Table 2. CFA results for POIS Form $M$ forms

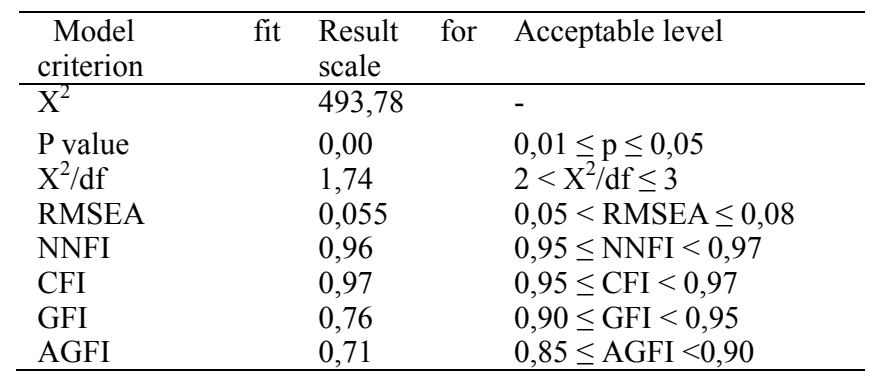




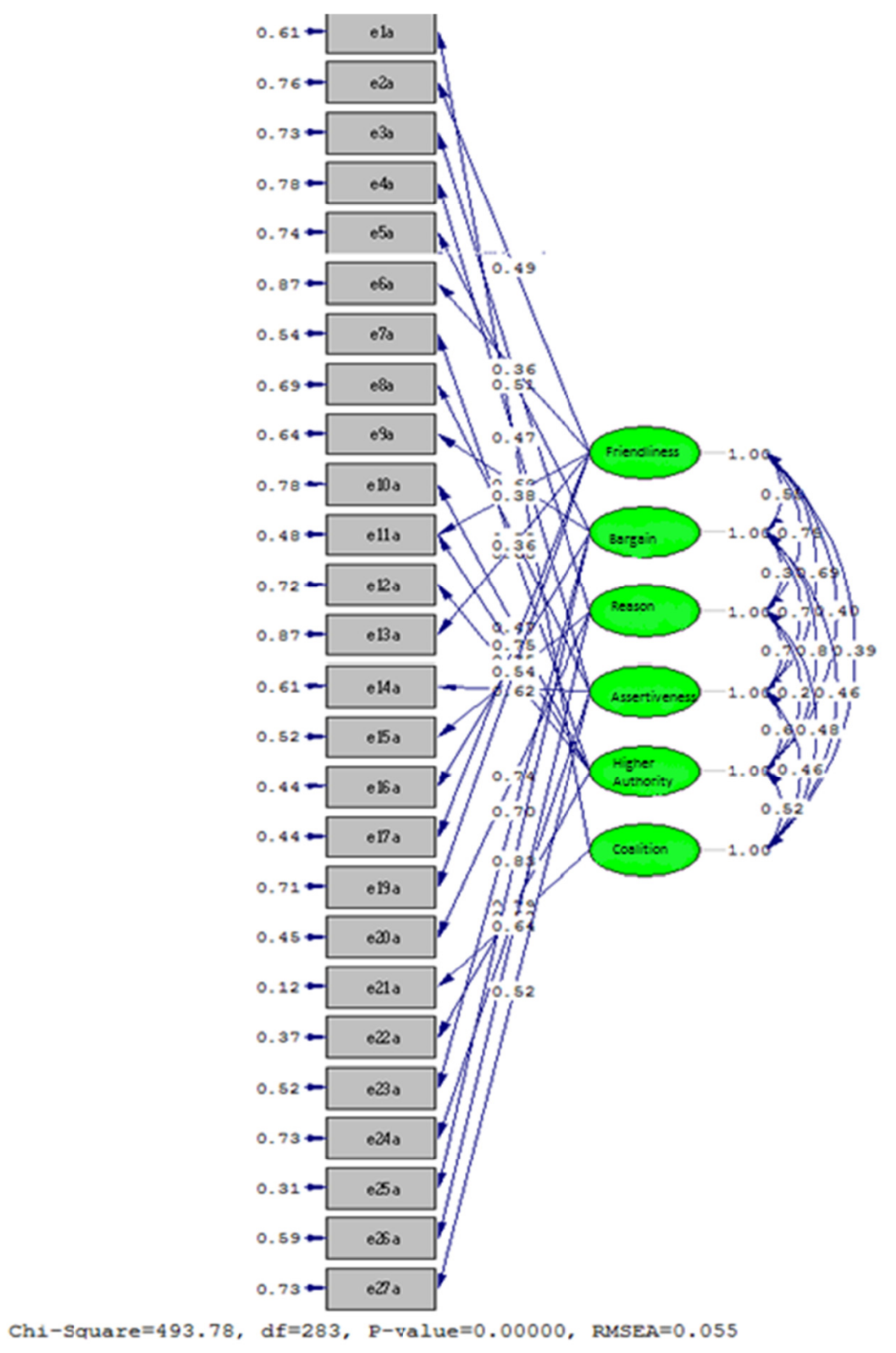

Figure 1. Results for POIS Form M forms

3.2 Profiles of Organizational Influence Strategies (POIS): Influencing Your Subordinates (form S) Analysis Results Confirmatory factor analysis indicated a reasonable model fit for "Profiles of Organizational Influence Strategies (POIS): Influencing Your Subordinates (Form S)" $\left(\mathrm{X}^{2}=808,53 ; \mathrm{P}=0,000, \mathrm{df}=474, \chi 2 / \mathrm{df}=1,70, \mathrm{CFI}=0,97, \mathrm{NNFI}=0,97\right.$, GFI $=0,70, \mathrm{AGFI}=0,65$ and RMSEA $=0,06)($ See Table 3$)$.

Table 3. CFA results for POIS Form $\mathrm{S}$ forms

\begin{tabular}{|c|c|c|}
\hline $\begin{array}{c}\text { Model } \\
\text { criterion }\end{array}$ & Result for scale & Acceptable level \\
\hline $\mathrm{X}^{2}$ & 808,53 & - \\
\hline P value & 0,00 & $0,01 \leq \mathrm{p} \leq 0,05$ \\
\hline$x^{2} / d f$ & 1.70 & $2<\mathrm{X}^{2} / \mathrm{df}<3$ \\
\hline RMSEA & 0,06 & $0,05<\mathrm{RM} \overline{\mathrm{MSE}} \leq 0,08$ \\
\hline NNFI & 0,97 & $0.95<$ NNFI $<0.97$ \\
\hline CFI & 0,97 & $0,95 \leq \mathrm{CFI}<0,97$ \\
\hline GFI & 0,70 & $0,90 \leq \mathrm{GFI}<0,95$ \\
\hline AGFI & 0,65 & $0,85 \leq \mathrm{AGFI}<0,90$ \\
\hline
\end{tabular}


The reliability and validity of POIS were investigated with a sample of 488 management figures in three countries by Leogan, Bond and $\mathrm{Fu}$ (2006). Confirmatory factor analysis indicated a reasonable model fit for the motivation section $(\mathrm{CFI}=0,65-0,89$; RMSEA $=0,059-0,169)$. As a result, POIS Form $\mathrm{S}$ forms of the profile were applied to the managers of Turkish secondary schools, and the validity and reliability of the profile were proved. The CFA diagram results for this model were also presented in Figure 2

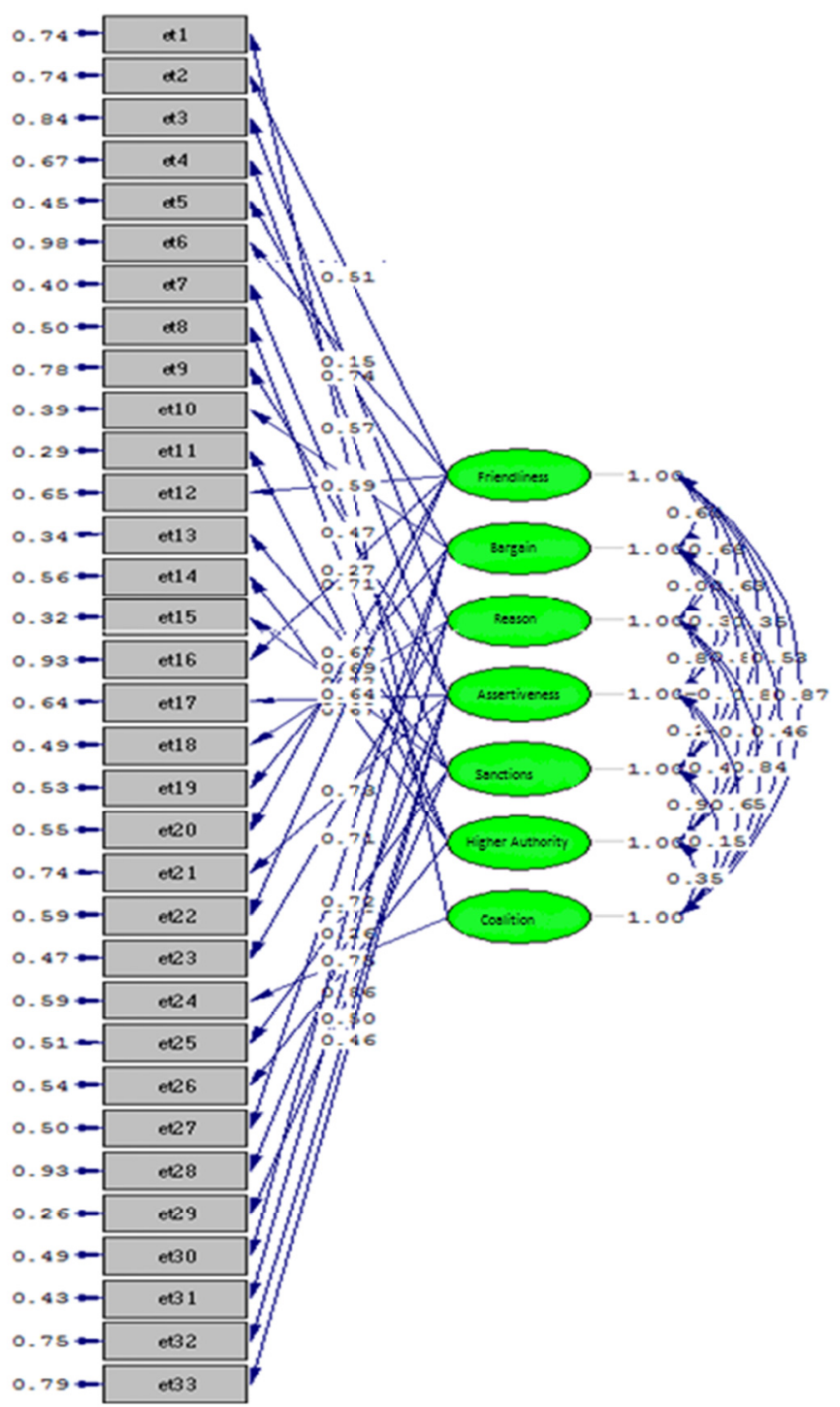

Chi-Square $=808.53$, df $=474, \mathrm{p}-\mathrm{value}=0.00000, \mathrm{RMSEA}=0.060$

Figure 2. Results for POIS Form S forms

\section{Discussion}

In this study, the POIS Form M and POIS Form S forms of the profile, which were developed by Kipnis and Schmidt (1999), were applied to teachers and managers in Turkish secondary schools, and the validity and reliability of the profile were proved. In order to confirm the profile's scope validity, experts' opinions were taken. Corroborative factor analysis was used to test the profile-supported structure.

At the end of the analysis of the Organizational Influence Strategies Profile: Influencing Manager (Form M) after DFA investigation of the 27 items (articles) six factors structure, it was concluded that the measurement model was appropriate. The organizational influence strategies scale consists of 27 items; 6 factors influencing the manager's scale (Form $\mathrm{M}$ ); the statistical value is chi-square $(\mathrm{X}=493,78 ; \mathrm{P}=0,000 \mathrm{sd}=283)$; and the adjustment index is $\mathrm{CFI}=0,97$, $\mathrm{NNFI}=0,96, \mathrm{GFI}=0,76 \mathrm{AGFI}=0,71$ and $\mathrm{RMSEA}=0,055$. With this form, the profile is composed of a six-factor structure. 
Schriesheim and Hinkin (1990) performed studies on four different samples. The first sample's GFI value was 0,75 , and its RMSEA value was 0,085 ; the GFI value of the second sample was 0,77 . This indicated that it had a valid structure. The influencing manager (Form M) profile was used for all four different samplings performed by Schriesheim and Hinkin (1990).

In Aydin and Pehlivan's (2010) organizational influence strategies profile on Turkish managers, they edited the influence manager scale (profile) (form M), did an exploratory factor analysis, and reported that the profile was valid and reliable. The same profile was used in Duyar, Aydin and Pehlivan's (2009) study on American and Turkish school managers, and they stated that the profile was valid in a report of the results of their exploratory analysis. In Karen's (1989) study, managers were asked how they influence their seniors. Knippenberg, Eijbern and Wilke (1999) gave the same results of exploratory factor analysis as Duyar, Aydin and Pehlivan (2009). Karen (1989) found the results of two halves validity analysis.

In regard to the Organizational Influence Strategies Profile: Influence the subordinate (Form S) profile is proved to be an appropriate pattern (model) after examining the DFA structure with six factors and 33 items (articles) that emerged from the original profile. Accordingly, in the organizational influencing strategies profile the statistics of influencing subordinate profile had 33 articles (items) and 7 factors, which are chi-square $(X=808,53 ; P=0,000, s d=474), C F I=$ $0,97, \mathrm{NNFI}=0,97, \mathrm{GFI}=0,70, \mathrm{AGFI}=0,65$ and RMSEA $=0,06$. In this form, the organizational influencing strategies profile showed that the influence the subordinate (form $\mathrm{S}$ ) profile is composed of a structure with seven factors. These data are consistent with the study carried out by Leogan, Bond and $\mathrm{Fu}(2006)$ in three countries with 488 managers.

According to the research results, it can be said that the structure validity and credibility coefficient of both organizational influencing strategies profile: influence subordinate (form A) and the organizational influencing strategies profile as a result of analysis are agreeable. Another important result of the study is that the item factor and error variance of the organizational influencing strategies profile: influence manager (form $\mathrm{M}$ ) and influence inferior (form S) are within the limits set in the literature.

Much research has been done regarding the outputs of influence tactics using the organizational influencing strategies profile. Furthermore, researchers like Landry, Porter and Lemon (1989), Schriesheim and Hinkin (1990) and Hochwarter et al. (2000) restructured the profile of Kipnis, Schmidt and Wilkinson (1980) and classified the tactics in different ways.

On the other hand, both the organizational influencing strategies profile: influence manager (form $\mathrm{Y}$ ) and influence inferior (form A) are required for some other studies. Some further studies that could be done are suggested below: (1) different criteria should be used to determine the number of the participants. According to Tabachnick and Fidell (2001), around 300 people are enough for the analysis. In order to decide on the participant number, Grimm and Yarnold (1995) gave the correlation of 5-10 item numbers. In confirmatory factor analysis, the number of parameters rate is 10 (Kline, 1998).

\section{Recommendations}

No matter how strong the prediction methods are, the possible insufficiency of the participants must be kept in mind, and research findings must be analyzed cautiously. In this context, a research hypothesis test must be repeated with similar participant groups. (2) With the organizational influence strategies profile on the manager and wage earner: influence manager (Form M) and organizational influence strategies profile and influencing inferior (form S), cross validation of both profiles must be done. (3) Profiles must be applied to managers and teachers of different branches.

\section{References}

Anderson, J. C., \& Gerbig, D. (1988). Structural Equation Modeling In Practice: A Review And Recommended Two-Step Approach, Psychological Bulletin, 103, 411-423. http://dx.doi.org/10.1037/0033-2909.103.3.411

Aslanargun, E. (2008). Ilkogretim ve Lise Mudurlerinin Okul Yonetiminde Kullandigi Guc Turleri. Ph. D. Thesis, Unpublished. Ankara: Ankara Universitesi Egitim Bilimleri Enstitusu.

Aydin, I., \& Pehlivan, Z. (2010). Strategies and Personality Types Used By Primary School Principals In Turkey To Influence Teacher (Ankara Case), Influence Teachers. Procedia Social And Behavioral Sciences, 2, 3652-3659. http://dx.doi.org/10.1016/j.sbspro.2010.03.568

Bacharach, B., \& Lawler, J. (1980). Power And Politics In Organizations. San Fransisco:Jessey-Bass Pub.

Boonstra, J., \& Bennebroek, G. K. (1989). Power Dynamics And Organizational Change: A Comparison Of Perspectives. European Journal Of Work And Organizational Psychology, 7, 97-120. http://dx.doi.org/10.1080/135943298398826

Brown, T. (2015). Confirmatory Factor Analysis for Applied Research, Second Edition. New York: The Guilford Press. 
Chatman, J. (1989). Improving Interactional Organizational Research: A Model Of Person-Organization Fit. Academy Of Management Review, 14(3), 333-349.

Chaturvedi, S. S., \& Srivastava, A. K. (2015). The Effect of Employees Organizational Commitment on Upward Influence Tactics and Employees' Career Success. An Indian International Journal of Research in Organizational Behavior and Human Resource Management, 3, 2.

Chong, P. M., Peng, T., Fu, P. P., Richards, M., Muethel, M., Caldas, M. P., \& Shang, Y. F. (2015). Relational Perspectives on Leaders' Influence Behavior: The Mediation of Western Leader-Member Exchange and Chinese Guanx Journal of Cross-Cultural Psychology, 46(1), 71-87. http://dx.doi.org/10.1177/0022022114554035

Cocivera, T. (2002). Influence In Organization: Testing An Integrative Model Agents' Decision-Making Processer For Selecting Tactics. Ph. D. Thesis, Unpublished. Guelph, Ontario: The University of Guelph.

Cropanzano, R., \& Mitchell, M. (2005). Social Exchange Theory: An Interdisciplinary Review. Journal Of Management, 31(6), 874-900. http://dx.doi.org/10.1177/0149206305279602

Culves, T. (1994). Influence Strategies and Trust in Public Schools. Ph. D. Thesis. USA: University Of Phoenix.

Dillard, J., Segrin, C., \& Harden, J. (1989). Primary And Secondary Goals in The Production Of Interpersonal Influence Messages. Communication Monographs, 56(1), 19-37. http://dx.doi.org/10.1080/03637758909390247

Dulaimi, M., Nepa, M., \& Park, N. (2005). A Hierarchical Structural Model Of Assessing Innovation And Project Performance. Construction Management and Economics, 23, 565-577. http://dx.doi.org/10.1080/01446190500126684

Duyar, I., Aydin, I., \& Pehlivan, Z. (2009). Analyzing Principal Influence Tactics From A Cross-Cultural Perspective: Do Preferred Influence Tactics And Targeted Goals Differ By National Culture? A W Wiseman (Editorler), Educational Leadership: Global Contexts And International Comparisons, 11,191-221. Bingley, UK: Volume 11 of the Book Series: International Perspectives on Education And Society.

Ekehammar, B. (1974). Interactionism In Personality From A Historical Perspective. Psychological Bulletin, 81, 1026-1048. http://dx.doi.org/10.1037/h0037457

Emerson, R. (1976). Social Exchange Theory. Annual Review of Sociology, 2, 335-362. http://dx.doi.org/10.1146/annurev.so.02.080176.002003

Erchul, W. P., Grissom, P. F., \& Getty, K. C. (2008). Studying Interpersonal Influence Within School Consultation: Social Power Base And Relational Communication Perspectives. V. S. Inw. P. Erchul (Editor), Handbook of Research in School Consultation (S. 293-322). New York: Taylor Ve Francis Group/Routledge.

Erchul, W., Paven, B. H., \& Whichard, S. M. (2001). School Psychologists and Teacher Perceptions of Social Power Bases in School Consultation. Journal of School Psychology, 39, 483-497. http://dx.doi.org/10.1016/S0022-4405(01)00085-1

Erogluer, K. (2011). The Relationship between Organizational Communication and the Aspects of Job Satisfaction: A Theoretical Study, Ege Academic Review, 11(1), 121-136.

French, T., \& Raven, B. (2001). The Basis Of Social Power (1959). I. Asherman, \& S. Asherman (Eds.), The Negotiation Source Book (2. Edt.) (61-73). Amherst: HRD Press.

Friedrich, T. (2010). Leadership In Teams: Investigating How Team Network Impact The Use Of Influence, Unpublished Doctoral's Thesis. Oklohoma: University Of Oklohoma.

Fu, P., \& Yukl, G. (2000). Perceived Effectiveness Of Influence Tactics In The United States And China. Leadership Quarterly, 11(2), 251-266. http://dx.doi.org/10.1016/S1048-9843(00)00039-4

George, D., \& Mallery, P. (2003). SPSS For Windows Step By Step: A Simple Guide And Reference 11.0 Update (4th $E d$.). Boston: Allyn Bacon.

Getty, K., \& Erchull, W. (2009). The Influence of Gender on The Likelihood Of Soft Social Power Strategies In The School Consultation. Psychology In The Schools, 46(5), 447-460. http://dx.doi.org/10.1002/pits.20389

Grimm, L. G., \& Yarnold, P. R. (1995). Reading and Understanding Multivariate Statistics, American Psychological Association, Washington,

Hambleton, R. K., Ph. D. Thesis, Unpublished. Pastsula, L (1999). Increasing The Validity Of Adapted Tests: Myths To Be Avoided and Guidelines For Improving Test Adaptation Practices. Journal Of Applied Testing Technology, 1, $1-12$. 
Hinkin, T., \& Schriesheim, C. (1990). Relationships Between Subordinate Perceptions Of Supervisor Influence Tactics And Attributed. Human Relation, 221-237. http://dx.doi.org/10.1177/001872679004300302

Hirokawa, R., \& Miyaharab, A. (1986). A Comparison Of Influence Strategies Utilized By Managers In American and Japanese Organizations. Communication Quarterly, 34(3), 250-265. http://dx.doi.org/10.1080/01463378609369639

Hu, L.T., \& Bentler, P. M. (1999). Cutoff Criteria for Fit Indices in Covariance Structure Analysis: Conventional Criteria versus New Alternatives. Structural Equation Modeling, 6, 1-55. http://dx.doi.org/10.1080/10705519909540118

Kalayci, S. (2009). SPSS Uygulamali Cok Degiskenli Istatislik Teknikleri, (4. Basim). Ankara: Asil Yayin Dagitim.

Karacor, S., \& Sahin, A. (2004). Orgutsel Iletisim Kurma Yontemleri ve Karsilasilan Iletisim Engellerine Yonelik Bir Arastirma, Sosyal ve Ekonomik Arastirmalar Dergisi, 8, 97-117.

Karen, L. J. (1989). A study of Power and Stress in the Manager Subordinate Dyad., Ph. D, Unpublished. Philadelphia: Temple University.

Kipnis, D., \& Schmidt, S. (1999). Profiles of Organizational Influence Strategies (POIS): Influencing Your Manager (Form M). San Diego, CA: University Associates, Inc.

Kipnis, D., \& Schmidt, S. (1999). Profiles of Organizational Influence Strategies (POIS): Influencing Your Subbordinates (Form S). San Diego, CA: University Associates, Inc.

Kipnis, D., \& Schmidt, S. M. (1988). Upward-Influence Styles: Relationship With Performance Evaluations, Salary and Stress. Administrative Science Quarterly, 33, 528-542. http://dx.doi.org/10.2307/2392642

Kipnis, D., Schmidt, S., Swaffin-Smith, C., \& Wilkinson, I. (1984). Patterns Of Managerial Influence: Shotgun Managers, Tacticians and Bystanders. Organizational Dynamics, 58-69. http://dx.doi.org/10.1016/0090-2616(84)90025-1

Kipnis, D., Schmith, S., \& Wilkinson, I. (1980). Intraorganizational Influence Tactics: Explorations in Getting One's Way. Journal Of Applied Psychology, 65(4), 440-452. http://dx.doi.org/10.1037/0021-9010.65.4.440

Kline, R. (1998). Principles and Practice of Structural Equation Modeling. New York: The Guilford Press.

Knippenberg, B., Eijbern, R., \& Wilke, H. (1999). The Use Of Hartand Soft Influence Tactics in Cooperative Task Groups. Group Processes and Intergroup Relation, 2(3), 231-244. http://dx.doi.org/10.1177/1368430299023002

Landry, G., Porter, A., \& Lemon, D. (1989). The Principals Power Tactics Survey: The Measurement Of Administrative Power Strategies Of Elementary School Principals. Educational and Psychological Measurement Spring, 49(1), 221-226. http://dx.doi.org/10.1177/0013164489491024

Leogan, J., Bond, M. H., \& Fu, P. (2006). Perceived Effectiveness Of Influence Strategies in The United States And Three Chinese Societies. International Journal of Cross Cultural Management, 6(1), 101-120. http://dx.doi.org/10.1177/1470595806064985

Lined, R. (2007). Using Power To Install Strategy: The Relationships Between Expert Power, Position Power, Influence Tactics and Implementation Success. Journal of Change Management, 7(2), 143-170. http://dx.doi.org/10.1080/14697010701531657

Lo, M. C. (2014). Leaders' Power and Downward Influence Tactics: The Impact of Power Congruence. Life Science Journal, 11(9), 166-174.

May-Chiun, L. M., Ramayah, T., \& Wang, Y. C. (2015). Sustainable Leadership: Power of Influence in MNCS in Malaysia, Applied Economics, 47(30).

Molm, L. D. (1991). Affect And Social Exchange: Satisfaction in Power-Dependence Relations. American Sociological Association, 475-493. http://dx.doi.org/10.2307/2096269

Newton, D. A., \& Burgoon, J. K. (1990). The Use And Consequences of Verbal Influence Strategies during Interpersonal Disagreements. Human Communication Research, 16, 477-518. http://dx.doi.org/10.1111/j.1468-2958.1990.tb00220.x

Onyekwere, E. (1989). Culture, Persuasion and The Management Of Environmental Attitudes. Africa Media Review, $3(2), 16-25$.

Raven, B. (2008). The Bases Of Power And The Power/Iteraction Model Of Interpersonal Influence. Analyses Of Social Issues And Policy, 8(1), 1-22. http://dx.doi.org/10.1111/j.1530-2415.2008.00159.x 
Raven, B., Schwarzwald, J., \& Koslowsky, M. (1998). Conceptualizing and Measuring A Power/Interactional Model of Interpersonal Influence. Journal of Applied Social Psychology, 28(4), 307-332. http://dx.doi.org/10.1111/j.1559-1816.1998.tb01708.x

Schermelleh-Engel, K., \& Moosbrugger, H. (2003). Evaluating The Fit Of Structural Equation Models: Tests of Significance and Descriptive Goodness-Of-Fit Measures. Methods of Psychological Research Online, 8(2), 23-74.

Schriesheim, C. A., \& Hinkin, T. R. (1990). Influence Tactics Used By Subordinates: A Theoretical And Empirical Analysis and Refinement of the Kipnis, Schmidt and Wilkinson Subscales. Journal of Applied Psychology, 75, 246-257. http://dx.doi.org/10.1037/0021-9010.75.3.246

Shah, J., \& Inamullah, H. M. (2011). Social Power Of Teacher. European Journal Of Social Science, 21(4), 516-521.

Simsek, O. (2007). Yapisal Esitlik Modellemesine Giris: Temel Ilkeler ve LISREL Uygulamalari. Istanbul: Ekinoks Yayinlari.

Stevens, J. (2002). Applied Multivariate Statistics For The Social Sciences. Mahwah, NJ: Lawrence Erlbaum.

Tabachnick, B. G., \& Fidell, L. S. (2001). Using Multivariate Statistics (4th Ed.). Needham Heights, MA: Allyn And Bacon.

Tasci, D., \& Eroglu, E. (2007). Yoneticilerin Kisilik Ozellikleri ile Kullandiklari Ikna ve Etkileme Taktiklerinin Kullanim Sikligi Arasindaki Iliskinin Degerlendirilmesi. Selcuk Universitesi Sosyal Bilimler Enstitusu Dergisi, 17, 255-546.

Thibaut, J. W., \& Kelley, H. H. (1959). The Social Psychology Of Groups. New York: Wiley.

Turner, J (2005). Explaining The Nature of Power: A Three-Process Theory. Europen Journal of Social Psychology, 1-22. http://dx.doi.org/10.1002/ejsp.244

Wayne, S., \& Ferris, G. (1990). Influence Tactics, Affect and Exchange Quality in Supervisor-Subordinate Interactions: A Laboratory Experiment and Field Study. Journal of Applied Psychology, 75(5), 487-499. http://dx.doi.org/10.1037/0021-9010.75.5.487

Yamaguchi, I. (2009). Influences of Organizational Communication Tactics on Trust With Procedural Justice Effects: A Cross-Cultural Study Between Japanese And American Workers. International Journal of Intercultural Relations, 33, 21-31. http://dx.doi.org/10.1016/j.jintrel.2009.01.002

Yukl, G. (2010). Leadership in Organization. 7th Edition. New Jersey: Pearson.

Yukl, G., \& Falbe, C. M. (1990). Influence Tactics and Objectives in Upward, Downward and Lateral Influence Attempts. Journal of Applied Psychology, 75(2), 132-140. http://dx.doi.org/10.1037/0021-9010.75.2.132

Yukl, G., \& Fu, P. (2003). Cross-Cultural Differences in Perceived Effectiveness of Influence Tactics for Initiating or Resisting Change. Applied Psichology: An International Review, 52(1), 68-82. http://dx.doi.org/10.1111/1464-0597.00124

Yukl, G., \& Michel, J. (2006). Proactive Influence Tactics and Leader-Member Exchange. C. S. H. B. (Eds), Power and Influence in Organizations: New Empirical and Theoretical Perspectives (p. 87-103). Portland: Information Age.

Yukl, G., \& Tracey, B. (1992). Consequences of Influence Tactics Used with Subordinates, Peers and the Boss. Journal of Applied Psychology, 77, 525-535. http://dx.doi.org/10.1037/0021-9010.77.4.525

Yukl, G., Chavez, C., \& Seiferst, C. (2005). Assessing the Construct Validity and Utility of Two New Influence Tactics. Journal of Organizational Behaviour, 26, 705-125. http://dx.doi.org/10.1002/job.335

\section{$(\mathrm{cc}) \mathrm{EY}$}

This work is licensed under a Creative Commons Attribution 3.0 License. 